Provided for non-commercial research and education use. Not for reproduction, distribution or commercial use.

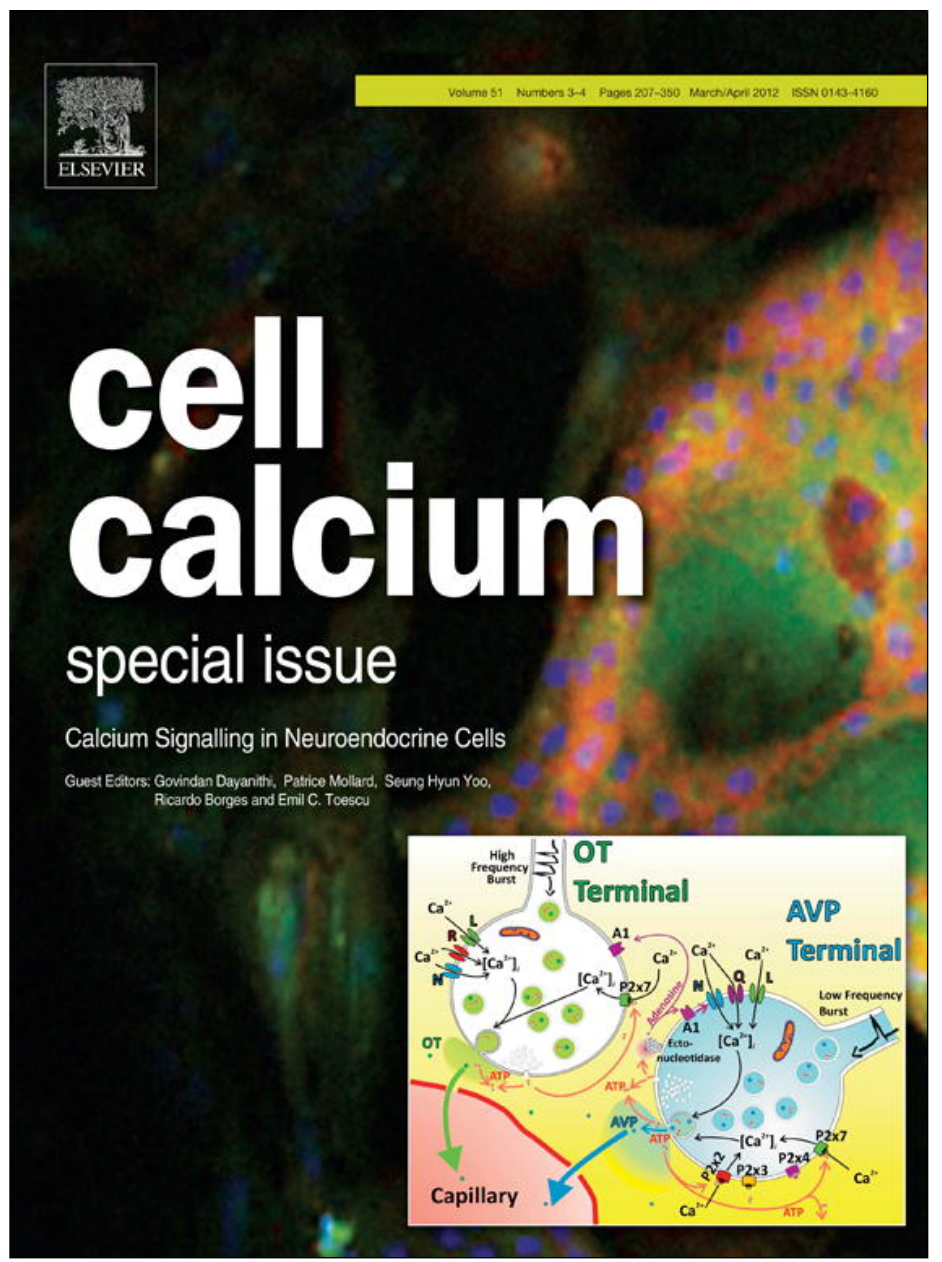

This article appeared in a journal published by Elsevier. The attached copy is furnished to the author for internal non-commercial research and education use, including for instruction at the authors institution and sharing with colleagues.

Other uses, including reproduction and distribution, or selling or licensing copies, or posting to personal, institutional or third party websites are prohibited.

In most cases authors are permitted to post their version of the article (e.g. in Word or Tex form) to their personal website or institutional repository. Authors requiring further information regarding Elsevier's archiving and manuscript policies are encouraged to visit:

http://www.elsevier.com/copyright 


\title{
Calcium dynamics in the secretory granules of neuroendocrine cells
}

\author{
Javier Álvarez* \\ Instituto de Biología y Genética Molecular (IBGM), Departamento de Bioquímica y Biología Molecular y Fisiología, Facultad de Medicina, Universidad de Valladolid and Consejo
} Superior de Investigaciones Científicas (CSIC), Ramón y Cajal, 7, E-47005 Valladolid, Spain

\section{A R T I C L E I N F O}

\section{Article history:}

Received 28 September 2011

Received in revised form

22 November 2011

Accepted 4 December 2011

Available online 30 December 2011

\section{Keywords:}

$\mathrm{Ca}^{2+}$

Secretory granules

Neuroendocrine

Chromaffin

Inositol trisphosphate receptor

Ryanodine receptor

$\mathrm{Ca}^{2+}$-ATPase

\begin{abstract}
A B S T R A C T
Cellular $\mathrm{Ca}^{2+}$ signaling results from a complex interplay among a variety of $\mathrm{Ca}^{2+}$ fluxes going across the plasma membrane and across the membranes of several organelles, together with the buffering effect of large numbers of $\mathrm{Ca}^{2+}$-binding sites distributed along the cell architecture. Endoplasmic and sarcoplasmic reticulum, mitochondria and even nucleus have all been involved in cellular $\mathrm{Ca}^{2+}$ signaling, and the mechanisms for $\mathrm{Ca}^{2+}$ uptake and release from these organelles are well known. In neuroendocrine cells, the secretory granules also constitute a very important $\mathrm{Ca}^{2+}$-storing organelle, and the possible role of the stored $\mathrm{Ca}^{2+}$ as a trigger for secretion has attracted considerable attention. However, this possibility is frequently overlooked, and the main reason for that is that there is still considerable uncertainty on the main questions related with granular $\mathrm{Ca}^{2+}$ dynamics, e.g., the free granular $\left[\mathrm{Ca}^{2+}\right]$, the physical state of the stored $\mathrm{Ca}^{2+}$ or the mechanisms for $\mathrm{Ca}^{2+}$ accumulation and release from the granules. This review will give a critical overview of the present state of knowledge and the main conflicting points on secretory granule $\mathrm{Ca}^{2+}$ homeostasis in neuroendocrine cells.
\end{abstract}

() 2011 Elsevier Ltd. All rights reserved.

\section{Introduction}

$\mathrm{Ca}^{2+}$ is an intracellular second messenger able to fulfill a variety of different functions in all cell types with no exception, both excitable and non-excitable cells. Let us just mention muscle contraction, neurotransmitter secretion, fertilization, proliferation, development, learning, memory or cell death [1]. This versatility can only be achieved thanks to a very precise control of its concentration at the subcellular level. In fact, activation of these processes usually takes place as a consequence of transient increases in the cytosolic $\left[\mathrm{Ca}^{2+}\right]$ in specific subcellular locations, which are variable depending on the process. These hot spots or local $\left[\mathrm{Ca}^{2+}\right]$ microdomains have a critical importance in $\mathrm{Ca}^{2+}$ signaling and their size and dynamics depends on the spatial disposition of the different $\mathrm{Ca}^{2+}$ transport systems (channels, exchangers, pumps, etc.) both in the plasma membrane and in intracellular organelles.

Because of the strong $\mathrm{Ca}^{2+}$ buffering of the cytosol (free $\mathrm{Ca}^{2+}$ constitutes only $1 \%$ of the total $\mathrm{Ca}^{2+}$ in the cytosol), diffusion of $\mathrm{Ca}^{2+}$ through the cytosol is severely limited, particularly during small, physiological, cell stimulations. Intracellular organelles are therefore essential to generate or control local $\left[\mathrm{Ca}^{2+}\right]$ microdomains at different intracellular locations. The first organelle that was known to have an important role in $\mathrm{Ca}^{2+}$ homeostasis was the endoplasmic reticulum (ER) [2]. This organelle behaves as a dynamic $\mathrm{Ca}^{2+}$

\footnotetext{
* Tel.: +34 983 423085; fax: +34983423588.

E-mail address: jalvarez@ibgm.uva.es
}

store. It accumulates $\mathrm{Ca}^{2+}$ in its lumen through the SERCA pumps up to near millimolar levels [3], and is able to induce a rapid release of $\mathrm{Ca}^{2+}$ to the cytosol via several specific $\mathrm{Ca}^{2+}$ channels present in its membrane ( $\mathrm{InsP}_{3}$ and ryanodine receptors, mainly). In addition, both the ER and the sarcoplasmic reticulum of muscle cells contain $\mathrm{Ca}^{2+}$-binding proteins with high-capacity and low-affinity that make the total calcium content of the ER to be about 10-fold larger than the free $\left[\mathrm{Ca}^{2+}\right]_{E R}$. The more abundant, calreticulin in the ER and calsequestrin in the SR, have $\mathrm{Ca}^{2+}$-affinities of 1-4 mM [2], close to the free $\left[\mathrm{Ca}^{2+}\right]_{E R}$, thus facilitating fast binding and release of $\mathrm{Ca}^{2+}$ following the changes in free $\left[\mathrm{Ca}^{2+}\right]_{\mathrm{ER}}$.

Another organelle with an important role in cell $\mathrm{Ca}^{2+}$ homeostasis is mitochondria, the organelle responsible of aerobic energy production in the cell. The ability of mitochondria to take up large amounts of $\mathrm{Ca}^{2+}$ was known since the sixties. However, the low $\mathrm{Ca}^{2+}$-affinity of the mitochondrial $\mathrm{Ca}^{2+}$ uniporter $\left(K_{\mathrm{M}}\right.$ above $10 \mu \mathrm{M}, 100$-fold higher than the resting cytosolic $\left[\mathrm{Ca}^{2+}\right], 100 \mathrm{nM}$, and 10 -fold higher than the usual peak cytosolic $\left[\mathrm{Ca}^{2+}\right]$ found during cell stimulation, about $1 \mu \mathrm{M}$ ) led to most researchers in the 1970s and 1980s to exclude a significant role in $\mathrm{Ca}^{2+}$ homeostasis for this organelle, at least under physiological conditions. Then, in the beginning of the 1990s, recombinant aequorin targeted to the mitochondria showed that mitochondrial $\left[\mathrm{Ca}^{2+}\right]$ was able to undergo rapid changes during cell activation [4]. That was the origin of a series of works by several research groups demonstrating that mitochondria were very active players in the control of the global cell $\mathrm{Ca}^{2+}$ homeostasis. In particular, because of the low- $\mathrm{Ca}^{2+}-$ affinity of their $\mathrm{Ca}^{2+}$ uptake mechanism, mitochondria are very well 
adapted to take up $\mathrm{Ca}^{2+}$ from local high- $\mathrm{Ca}^{2+}$ microdomains, such as those formed after the activation of plasma membrane or endoplasmic reticulum $\mathrm{Ca}^{2+}$ channels. Mitochondria can therefore modulate important cellular functions such as neurotransmitter secretion by acting as local $\mathrm{Ca}^{2+}$ sinks [5].

The subject of this review, the secretory granules, constitutes one of the less known compartments in terms of $\mathrm{Ca}^{2+}$ dynamics. It is widely known that the increase in intracellular $\left[\mathrm{Ca}^{2+}\right]$ levels triggers exocytosis of a pool of docked secretory vesicles in neuronal and neuroendocrine cells. These vesicles are attached to the plasma membrane and are also very close to portions of ER and mitochondria. Thus, it is generally assumed that the $\mathrm{Ca}^{2+}$ required for exocytosis may enter from the extracellular medium through several kinds of plasma membrane $\mathrm{Ca}^{2+}$ channels [6] or be released from the endoplasmic reticulum through either inositol trisphosphate $\left(\mathrm{InsP}_{3}\right)$ or ryanodine receptors [7]. Nearby mitochondria may also contribute to modulate the size of the local $\left[\mathrm{Ca}^{2+}\right]$ microdomain responsible for vesicle fusion and secretion. However, it is hardly mentioned that the main $\mathrm{Ca}^{2+}$-store in some excitable cells resides in the secretory vesicles. In chromaffin cells, secretory granules contain about $60 \%$ of the total cellular calcium [8], and the total calcium concentration inside the granules has been estimated to be around $40 \mathrm{mM}$ [9], much higher than that in the ER (about 5-10 mM, see [2]). Of course, an attractive possibility would be that intragranular calcium could contribute to its own secretion by being released through $\mathrm{Ca}^{2+}$ channels placed in the granule membrane. In that way, $\mathrm{Ca}^{2+}$ would be released precisely in the right place to trigger secretion. What is then the reason for this apparent oversight? As we will discuss in this review, the main reason for that is that there is still little and sometimes contradictory information on the dynamics of $\mathrm{Ca}^{2+}$ in the granules. Thus, the main aspects of $\mathrm{Ca}^{2+}$ homeostasis in the granules, that is, the free $\left[\mathrm{Ca}^{2+}\right]_{\mathrm{SG}}$ and the mechanisms for $\mathrm{Ca}^{2+}$ accumulation and release, are still controversial.

\section{The problem of the free and total calcium concentration in the secretory granules}

Studies in the 1980s showed that the total calcium concentration in the secretory granules is $40-80 \mathrm{nmol} / \mathrm{mg}$ of protein $[10,11]$, which considering a protein/water relationship in the granules of about $0.5 \mathrm{mg} / \mu \mathrm{l}$ [12], implies that the total calcium concentration in the granules is $20-40 \mathrm{mM}$. Winkler and Westhead [9] calculated a total of $90,000 \mathrm{Ca}^{2+}$ ions for a vesicle with $270 \mathrm{~nm}$ internal diameter, which means a concentration of $15 \mathrm{mM}$. Studies of total calcium made by electron energy loss imaging spectroscopy in PC12 cells show also clearly that dense granules have a high calcium content $(>10 \mathrm{mM})$, with a signal comparable to that obtained in the Golgi complex and some regions of the ER [13]. Accordingly, in PC12 cells, the acidic calcium pool accounted for $170 \mu \mathrm{mol} / \mathrm{l}$ cell water, which corresponds to an internal total concentration of about $30 \mathrm{mM}$ [14]. This high calcium content is not exclusive of chromaffin granules but instead it is also found at similar or even higher values in most types of secretory granules, e.g. zymogen granules of pancreatic acinar cells [15], small synaptic vesicles of the neuromuscular junction [13], insulin granules [16] and many others (see [17] for a review).

Therefore, secretory granules appear to be the organelles with the higher calcium content of the cell. Other organelles with high calcium content are the endoplasmic reticulum and Golgi apparatus. Electron microscopy techniques have shown that the total calcium content of the ER from different cell types is in the range of $5-50 \mathrm{mM}$, with the highest values in the terminal cisternae of the sarcoplasmic reticulum and mean values of $5-10 \mathrm{mM}[2,18]$, that is, $5-10$-fold lower than in the secretory granules. The free $\left[\mathrm{Ca}^{2+}\right]$ in the ER has been also measured with low- $\mathrm{Ca}^{2+}$-affinity aequorin and is in the $500-800 \mu \mathrm{M}$ range [7], so that the $\mathrm{Ca}^{2+}$-bound $/ \mathrm{Ca}^{2+}$ free relationship in the ER is about 10. In addition, the total calcium distribution in the ER is heterogeneous, with strongly positive cisternae (including the nuclear envelope) lying in the proximity of or even in direct continuity with other, apparently negative cisternae [13]. This heterogeneity must surely reflect the distribution of the $\mathrm{Ca}^{2+}$-binding proteins in the lumen of the ER, as most of the calcium content of the ER is bound with low affinity $\left(K_{\mathrm{d}}=1-4 \mathrm{mM}\right)$ to several $\mathrm{Ca}^{2+}$-binding proteins, mainly calreticulin in the ER and calsequestrin in the SR $[2,18]$. The $K_{\mathrm{d}}$ for $\mathrm{Ca}^{2+}$ binding of these proteins is therefore close to the free $\left[\mathrm{Ca}^{2+}\right]$ in the ER, assuring an efficient binding.

Many studies have tried to estimate the free $\left[\mathrm{Ca}^{2+}\right]$ in the secretory granules. Bulenda and Gratzl [10] and Haigh et al. [8], using null-point titration techniques, found values of $24 \mu \mathrm{M}$ and $5.6 \mu \mathrm{M}$, respectively, in isolated acidic chromaffin vesicles. In mast cell granules, studies with fluorescent dyes showed a resting intraluminal free $\left[\mathrm{Ca}^{2+}\right]$ of $25 \mu \mathrm{M}$ [19]. In the $\beta$-cell line MIN6, data obtained with targeted aequorin indicated a free $\left[\mathrm{Ca}^{2+}\right]$ in the vesicles around $50 \mu \mathrm{M}[20]$. These values contrast with the $1.4 \mu \mathrm{M}$ $\left[\mathrm{Ca}^{2+}\right]$ value obtained by Mahapatra et al. [21] in PC12 chromaffin granules, using also targeted aequorin. The discrepancy may probably be due to the higher $\mathrm{Ca}^{2+}$-affinity of the aequorin type used in the last study. Because aequorin is consumed faster in high-Ca ${ }^{2+}$ environments, high- $\mathrm{Ca}^{2+}$-affinity aequorin is rapidly consumed in those regions and finally tends to reflect only the behavior of minor compartments with low $\left[\mathrm{Ca}^{2+}\right][22]$. Using an aequorin with lower $\mathrm{Ca}^{2+}$-affinity and correcting for the effect of acidic $\mathrm{pH}$ on aequorin luminescence, we have reported free $\left[\mathrm{Ca}^{2+}\right]$ values of $50-100 \mu \mathrm{M}$ in chromaffin granules [23] and 20-40 $\mu \mathrm{M}$ in PC12 and INS1 cells [24]. We should note also that the small size of some of the vesicles poses some restrictions to the possible values of free granular $\left[\mathrm{Ca}^{2+}\right]$. Let us just mention that for a small synaptic vesicle, with a diameter of $50 \mathrm{~nm}, 25 \mu \mathrm{M}\left[\mathrm{Ca}^{2+}\right]$ would be obtained with only 1 $\mathrm{Ca}^{2+}$ ion, and even for a large dense core vesicle of $200 \mathrm{~nm}$ diameter, just $2-3 \mathrm{Ca}^{2+}$ ions per vesicle would represent $1 \mu \mathrm{M}\left[\mathrm{Ca}^{2+}\right]$ (that would give figures of $100-300$ free $\mathrm{Ca}^{2+}$ ions per vesicle).

In conclusion, the free $\left[\mathrm{Ca}^{2+}\right]$ in several types of secretory granules appears to range between 20 and $100 \mu \mathrm{M}$. These values are significantly lower, nearly by one order of magnitude, than the free $\left[\mathrm{Ca}^{2+}\right]$ in the endoplasmic reticulum, which is about $500 \mu \mathrm{M}[3,25]$. Given that the total calcium content is larger in the vesicles than in the ER also by nearly one order of magnitude in terms of concentration, this means that the $\mathrm{Ca}^{2+}$ bound $/ \mathrm{Ca}^{2+}$ free relationship is much higher (almost two orders of magnitude) in the vesicles than in the ER, from values of 10-20 in the ER to nearly 1000 in the vesicles. The question then is where all those $\mathrm{Ca}^{2+}$-binding sites are. It is generally assumed that the large calcium storing capacity of the secretory granules is mainly due to the presence of high concentrations (about $2 \mathrm{mM}$ ) of the proteins chromogranin A and $B$ and secretogranin [26]. In bovine chromaffin cells, chromogranin A constitutes about $90 \%$ of these $\mathrm{Ca}^{2+}$-binding proteins $(1.8 \mathrm{mM})$, and it is able to bind $55 \mathrm{~mol}$ of $\mathrm{Ca}^{2+}$ per mol of protein, with a $K_{\mathrm{d}}$ of $4 \mathrm{mM}$ [26]. The $\mathrm{Ca}^{2+}$-binding capacity of these proteins is therefore very large and could store up to $100 \mathrm{mM}$ total calcium. However, the affinity is too low if we consider that the free $\left[\mathrm{Ca}^{2+}\right]_{\mathrm{SG}}$ remains below $100 \mu \mathrm{M}$. In fact, even considering a free granular $\left[\mathrm{Ca}^{2+}\right]$ of $100 \mu \mathrm{M}$, binding to a protein with a $K_{\mathrm{d}}$ of $4 \mathrm{mM}$ would hardly fill $2.5 \%$ of the available binding sites. In our case, this binding would explain $2.5 \mathrm{mM}$ of the stored calcium, that is, less than $10 \%$ of the calcium present in the granules.

How can then we explain the large $\mathrm{Ca}^{2+}$-storing capacity of the granules? There are several alternatives: (i) the $\mathrm{Ca}^{2+}$ affinity of these $\mathrm{Ca}^{2+}$-binding proteins could be different in the conditions of the secretory granules, that is, at very high protein concentrations $(0.5 \mathrm{mg} / \mu \mathrm{l})$ and in the presence of $500-1000 \mathrm{mM}$ catecholamines 
and 125-300 mM ATP; (ii) early studies described a significant number of higher affinity $\mathrm{Ca}^{2+}$-binding sites in vesicle matrix proteins, that would be able to bind up to $180 \mathrm{nmol} \mathrm{Ca}^{2+} / \mathrm{mg}$ protein with affinities in the $100-300 \mu \mathrm{M}$ range depending on the $\mathrm{pH}$ and ionic conditions $[27,28]$; and (iii) part of the calcium could also be bound to other vesicle components, such as nucleotides or lipids. Regarding the nucleotides, they are present at high concentrations and can bind $\mathrm{Ca}^{2+}$ with a $K_{\mathrm{d}}$ in the $100-300 \mu \mathrm{M}$ range depending on the $\mathrm{pH}$ and ionic conditions [27]. However, catecholamines and ATP have been shown to interact at the concentrations found in the granules forming highly non-ideal solutions that considerably reduce osmotic pressure [29]. Given that this interaction does not require calcium, and that most of vesicle ATP and catecholamines appear to be involved in these interactions, probably only a small part of the total ATP is available to bind $\mathrm{Ca}^{2+}$ in the vesicles.

A final point regards the availability of the stored calcium for exchange from the binding sites. In the ER and SR, the $\mathrm{Ca}^{2+}$ bound to calreticulin or calsequestrin is in fast equilibrium with the free $\mathrm{Ca}^{2+}$, and it is therefore readily available for release from the binding sites when the luminal free $\left[\mathrm{Ca}^{2+}\right]$ is reduced. In that way, when the $\mathrm{Ca}^{2+}$-channels in the ER or SR (e.g., InsP 3 or ryanodine receptors) are activated, all the stored $\mathrm{Ca}^{2+}$ can contribute to the release into the cytosol. In the case of the secretory granules, some reports suggest that at least part of the stored calcium is relatively immobile or exchanges very slowly with the free $\mathrm{Ca}^{2+}$ pool. Clemente and Meldolesi [15] found that zymogen granules have a very slow rate of ${ }^{45} \mathrm{Ca}$ accumulation and release compared with other organelles, suggesting that the stored $\mathrm{Ca}^{2+}$ could play mainly a structural role in the architecture of the organelle. Similarly, ${ }^{45} \mathrm{Ca}$ flux experiments performed in $\mathrm{PC} 12$ cells showed that the granule $\mathrm{Ca}^{2+}$ pool was extraordinarily stable in periods of hours in EGTA-containing medium, and very slow to label [14], concluding that the stored $\mathrm{Ca}^{2+}$ would only serve to keep granule components together and to be discharged to the extracellular space by exocytosis. The question then relies in the nature and the physical state of the contents of the granule. Evidence from several techniques indicates that no important fraction of the small molecules of the granule is in an immobilized or precipitated form (see [9] for a review). However, complexes between ATP and catecholamines and perhaps other components must necessarily exist to explain the osmotic properties of the granule [29]. In addition, chromogranins have been shown to aggregate or form tetramers in a $\mathrm{Ca}^{2+}$-dependent way $[28,30,31]$. These complexes could perhaps trap in a stable form some of the stored calcium.

As a conclusion, $\mathrm{Ca}^{2+}$ ions in the secretory granules can be in three different states: (i) a stable, slowly exchanging pool which may be important for the structure of the granular components; (ii) a pool bound to chromogranins or other granular components with an affinity close to the free $\left[\mathrm{Ca}^{2+}\right]_{S G}$, readily available for exchange and whose size may depend on $\left[\mathrm{Ca}^{2+}\right]_{\mathrm{c}}$ variations or other cellular conditions; and (iii) the free $\mathrm{Ca}^{2+}$ pool. The relative size of these pools may depend on the type of granule and the cellular conditions.

\section{Mechanisms of $\mathrm{Ca}^{2+}$ accumulation in the secretory granules}

If the free $\left[\mathrm{Ca}^{2+}\right]_{S G}$ is in the $20-100 \mu \mathrm{M}$ range, there should be in the membrane of the secretory granules active mechanisms to accumulate this ion in the matrix, given that its concentration in the cytosol is nearly 1000 -fold lower. Several candidates have been proposed for this role (see the cartoon in Fig. 1).

Krieger-Brauer and Gratzl [32] found evidence for the presence of a $2 \mathrm{Na}^{+} / 1 \mathrm{Ca}^{2+}$ exchange in the membrane of the secretory granules of bovine chromaffin cells. The system was $\mathrm{pH}$-independent and had high affinity for $\mathrm{Ca}^{2+}(0.28 \mu \mathrm{M}$ [33]), so that it was still partially active at $100 \mathrm{nM}$ extragranular $\left[\mathrm{Ca}^{2+}\right]$, although the rate increased at higher concentrations. Haigh and Phillips [34] proposed that $\mathrm{Na}^{+} / \mathrm{Ca}^{2+}$ exchange could be coupled to the $\mathrm{H}^{+}$pump via a Na$/ \mathrm{H}^{+}$exchange, but the rates of uptake they found in chromaffin granule ghosts were very slow. The capacity of this system to accumulate $\mathrm{Ca}^{2+}$ in the vesicles depends on the magnitude of the $\mathrm{Na}^{+}$ gradient. The intragranular $\left[\mathrm{Na}^{+}\right]$was estimated by Kriegler-Brauer and Gratzl [32,33] about $50 \mathrm{mM}$. Haigh et al. [8] found also that the sum of the intragranular $\left[\mathrm{Na}^{+}\right]$and $\left[\mathrm{K}^{+}\right]$was $50-60 \mathrm{mM}$, the actual amount of each one depending of the isolation procedure. In any case, this means that the $\left[\mathrm{Na}^{+}\right]$gradient between the granule matrix and the cytosol is no larger than 3-fold. Thus, with a stoichiometry of $2 \mathrm{Na}^{+} / 1 \mathrm{Ca}^{2+}$, this system would not be able to accumulate $\mathrm{Ca}^{2+}$ more than 10-fold inside the granules, much less than the existing gradient. In fact, with a $\left[\mathrm{Ca}^{2+}\right]$ gradient of 1000 -fold, this system would mainly work releasing $\mathrm{Ca}^{2+}$ from the vesicles in exchange for $\mathrm{Na}^{+}$. It has been actually proposed that $\mathrm{Na}^{+} / \mathrm{Ca}^{2+}$ exchange may mediate the increase in intravesicular $\left[\mathrm{Na}^{+}\right]$that coincides with the onset of secretion in neurohypophysial nerve endings [35].

The presence of $\mathrm{a} \mathrm{Ca}^{2+} / \mathrm{H}^{+}$antiport has been reported in synaptic vesicles of brain cortex [36]. Combined with the $\mathrm{H}^{+}$-ATPase and assuming a stoichiometry of $1 \mathrm{Ca}^{2+} / 2 \mathrm{H}^{+}$, this system would be able to accumulate $\mathrm{Ca}^{2+}$ nearly 1000 -fold into the vesicles. However, that transport system showed very low $\mathrm{Ca}^{2+}$ affinity for $\mathrm{Ca}^{2+}$ entry, starting to be active at cytosolic $\left[\mathrm{Ca}^{2+}\right]$ around $100 \mu \mathrm{M}$. Thus, under these conditions it could not be involved in physiological $\mathrm{Ca}^{2+}$ uptake into the vesicles, although it may perhaps mediate $\mathrm{Ca}^{2+}$-release from the vesicles following changes in the $\left[\mathrm{H}^{+}\right]$gradient. In fact, the disruption of the vesicular $\mathrm{pH}$ gradient induces a significant leak of $\mathrm{Ca}^{2+}$ from the vesicles [37,38].

The last possibility is a direct ATP-dependent mechanism for $\mathrm{Ca}^{2+}$ accumulation, that is, a $\mathrm{Ca}^{2+}$-ATPase. The sarco-endoplasmic reticulum $\mathrm{Ca}^{2+}$-ATPase (SERCA) inhibitor 2,5-diterbutyl benzohydroquinone (BHQ) has been shown to inhibit $\mathrm{Ca}^{2+}$ uptake into isolated synaptic vesicles [39]. In platelets, the acidic $\mathrm{Ca}^{2+}$ pool was controlled both by a Ca ${ }^{2+} / \mathrm{H}^{+}$exchange and by a BHQ-sensitive SERCA $3[40,41]$. Similarly, loading with $\mathrm{Ca}^{2+}$ of dense-core insulin storage granules of mouse pancreatic $\beta$-cells was sensitive to both SERCA inhibitors BHQ and thapsigargin [42]. More recently, using aequorin to monitor intragranular $\left[\mathrm{Ca}^{2+}\right]$ we have also described both in chromaffin cells and in the cell lines PC12 and INS1 [23,24], that $\mathrm{Ca}^{2+}$ uptake by the secretory granules was ATP-dependent and fully sensitive to thapsigargin and BHQ (see Fig. 1). On the other hand, in the $\beta$-cell line MIN6, $\mathrm{Ca}^{2+}$ uptake was shown to be ATP-dependent but insensitive to thapsigargin [20], suggesting the involvement of a different type of $\mathrm{Ca}^{2+}$-ATPase, the secretory pathway $\mathrm{Ca}^{2+}$-ATPase or ATP2C1, which is also present in the Golgi apparatus together with the SERCA [43].

Recent data obtained from proteomic studies of the secretory granules in several cell types provide new important information on this point, though do not clarify it. A recent proteomic study in the secretory granules of chromaffin cells has identified 371 distinct soluble proteins and 384 distinct membrane proteins [44]. However, among them, the only membrane protein able to accumulate calcium in the vesicles was a sodium/potassium/calcium exchanger. Previous studies in pancreatic zymogen granules [45] (371 proteins identified) and corticotropes dense-core secretory granules [46] (150 proteins identified) had not identified any protein related with $\mathrm{Ca}^{2+}$ accumulation. Instead, a proteomic study that identified 270 proteins in secretory vesicles from insulinoma NIT- 1 cells showed the presence of SERCA2 in the membrane of the vesicles [47], but another study in the insulin-secreting cell line INS-1E that identified 150 vesicular proteins failed to find any $\mathrm{Ca}^{2+}$ transport protein [48]. 


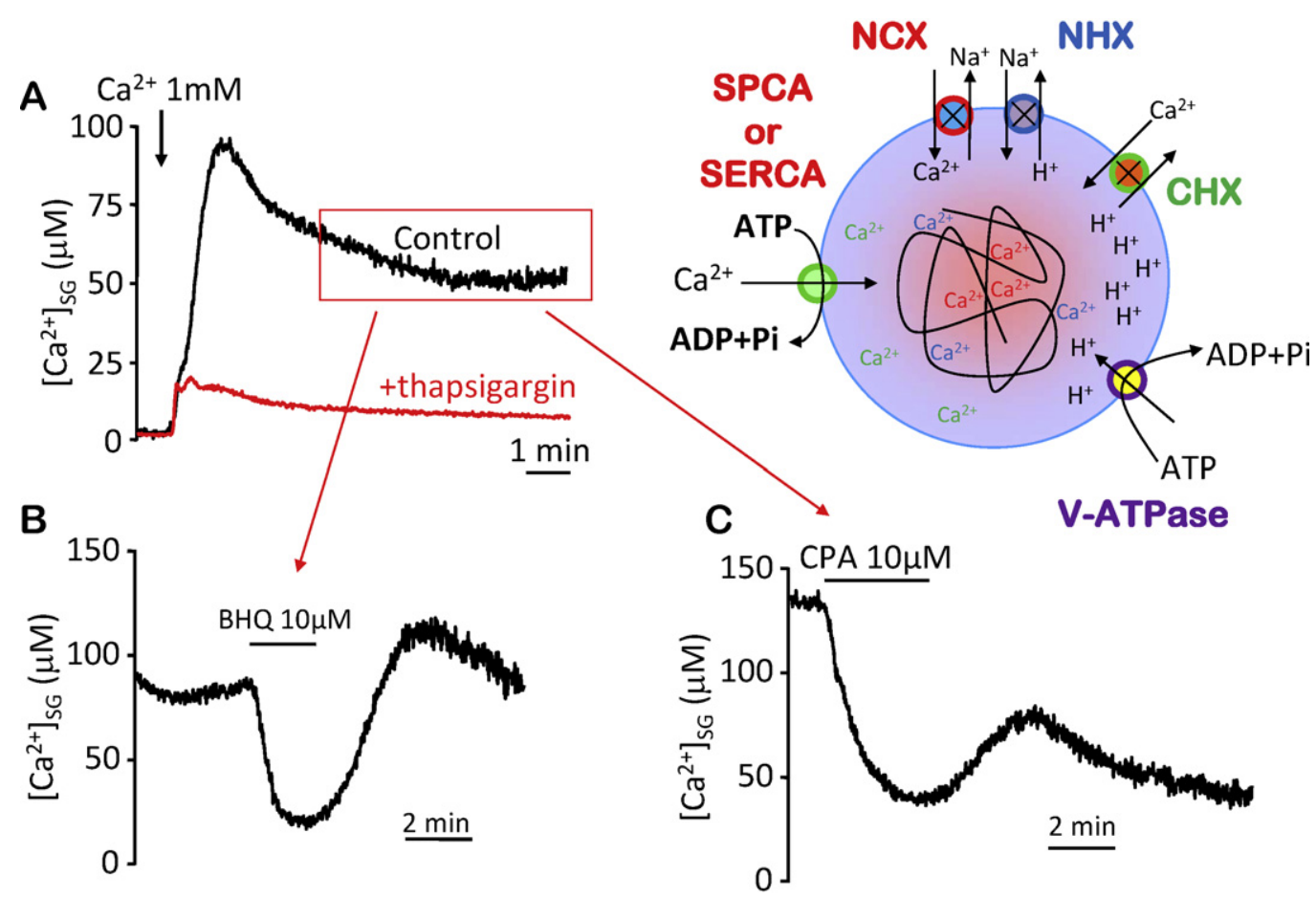

Fig. 1. Mechanisms of $\mathrm{Ca}^{2+}$ accumulation in the granules. Traces correspond to $\left[\mathrm{Ca}^{2+}\right]_{\mathrm{sG}}$ measurements made with chromaffin cells expressing aequorin targeted to the secretory granules (modified from Ref. [23]). Panel A shows the increase in $\left[\mathrm{Ca}^{2+}\right]_{\mathrm{sG}}$ that occurs upon readdition of $\mathrm{Ca}^{2+} 1 \mathrm{mM}$ to the extracellular medium in Ca ${ }^{2+}$-depleted cells, and its inhibition by thapsigargin. Panels B and C show that the SERCA inhibitors 2,5-diterbutyl benzohydroquinone (BHQ) and cyclopiazonic acid (CPA) both reversibly inhibit $\mathrm{Ca}^{2+}$ uptake by the granules when added after refilling of the granules with $\mathrm{Ca}^{2+}$ (at the point marked by the red rectangle in panel $\mathrm{A}$ ). The cartoon resumes the possible mechanisms for $\mathrm{Ca}^{2+}$ accumulation in the granules: $\mathrm{Ca}^{2+}$ pumps, either SERCA or secretory pathway $\mathrm{Ca}^{2+}-\mathrm{ATPase}(\mathrm{SPCA}), \mathrm{Na}^{+} / \mathrm{Ca}^{2+}$ exchange coupled with $\mathrm{Na}^{+} / \mathrm{H}^{+}$ exchange, and $\mathrm{Ca}^{2+} / \mathrm{H}^{+}$exchange. The exchangers would be energized by the $\mathrm{H}^{+}$gradient created by the $\mathrm{H}^{+}$-ATPase. $\mathrm{Ca}^{2+}$ inside the granules is represented in three possible forms, strongly bound (red), bound and readily releasable (blue) and free (green).

\section{Mechanisms of $\mathrm{Ca}^{2+}$ release from the secretory granules}

If the $\mathrm{Ca}^{2+}$ stored in the granules has to be released during cell stimulation to cooperate with $\mathrm{Ca}^{2+}$ coming from other sources in triggering vesicle fusion and secretion, the granules need to have $\mathrm{Ca}^{2+}$ transport systems that are able to open or activate during cell stimulation (see the cartoon in Fig. 2). The first system to be proposed for that role in chromaffin cells was the inositol $1,4,5$-trisphosphate receptor $\left(\operatorname{InsP}_{3} \mathrm{R}\right)$. The presence of $\operatorname{InsP}_{3} \mathrm{R}$ in secretory granules has been a highly conflicting point over the

\section{A}

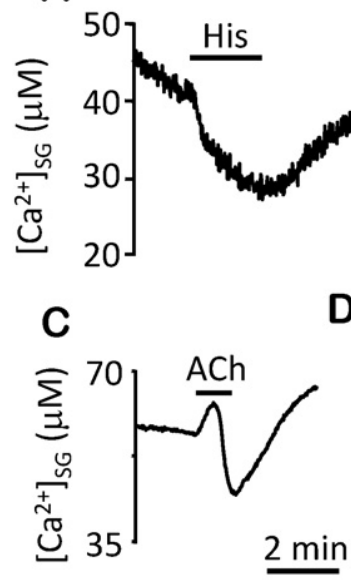

B

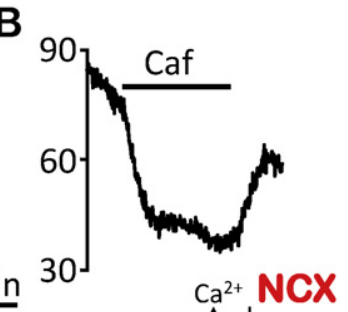

\section{$2 \min$}
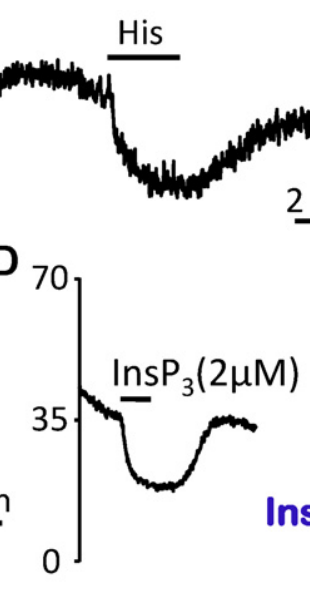

NAADPR

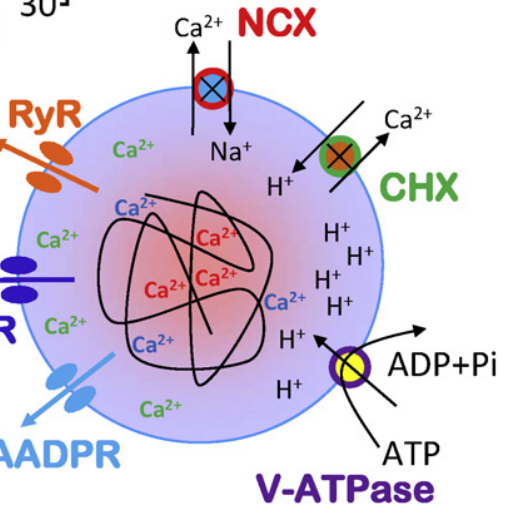

Fig. 2. Mechanisms of $\mathrm{Ca}^{2+}$ release from the granules. Traces correspond to $\left[\mathrm{Ca}^{2+}\right]_{\mathrm{SG}}$ measurements made with chromaffin cells expressing aequorin targeted to the secretory granules (modified from Ref. [23]). Panels A and B show the $\mathrm{Ca}^{2+}$ release from the granules induced by histamine (via InsP $\mathrm{P}_{3}$ production) and by caffeine (RyR activator). Panel $\mathrm{C}$ shows the effect of the natural agonist acethylcholine, and panel $\mathrm{D}$ shows the $\mathrm{Ca}^{2+}$ release induced directly by InsP $\mathrm{P}_{3}$ in permeabilized cells. The cartoon resumes the possible mechanisms for $\mathrm{Ca}^{2+}$ release from the granules: three $\mathrm{Ca}^{2+}$ channels $\left(\mathrm{InsP}_{3}\right.$, ryanodine and NAADP receptors), and 2 exchangers, $\mathrm{Na}^{+} / \mathrm{Ca}^{2+}$ exchanger and $\mathrm{H}^{+} / \mathrm{Ca}^{2+}$ exchanger, that under some circumstances, namely after an increase in granular $\mathrm{pH}$, may act extruding $\mathrm{Ca}^{2+}$ from the vesicles. 
last 20 years. In 1990, Yoo and Albanesi [49] reported that inositol 1,4,5-trisphosphate $\left(\mathrm{InsP}_{3}\right)$ released $\mathrm{Ca}^{2+}$ from chromaffin cells secretory vesicles. Immunocytochemical localization of all three types of InsP $\mathrm{P}_{3} \mathrm{R}$ in serially sectioned bovine chromaffin cells showed that the secretory granules contained about $60 \%$ of the InsP ${ }_{3} \mathrm{R}$ in the cell [50], and additional evidence for the presence of InsP $_{3} \mathrm{R}$ in the granules was the finding that both chromogranin $\mathrm{A}$ and $\mathrm{B}$ interact with $\operatorname{InsP}_{3} \mathrm{R}$ and modulate its activity [26,51-54]. More recently, using targeted aequorin to measure $\left[\mathrm{Ca}^{2+}\right]$ in the secretory granules of chromaffin cells and the neurosecretory cell lines PC12 and INS1 $[23,24]$, we have shown that $\mathrm{InsP}_{3}$ and $\mathrm{InsP}_{3}$-releasing agonists can release $\mathrm{Ca}^{2+}$ from the granular compartment (see Fig. 2).

Ins $\mathrm{P}_{3} \mathrm{R}$ have been also detected in other types of secretory granules. Isolated zymogen granules were found to release $\mathrm{Ca}^{2+}$ in the presence of InsP $\mathrm{P}_{3}$ [55], although the same authors have also reported that in intact cells most of the $\mathrm{Ca}^{2+}$ released by $\mathrm{InsP}_{3}$ comes from the ER [56]. In mast cell granules [19] and mucin granules of goblet cells [57], InsP $\mathrm{P}_{3}$ induced periodic oscillations of luminal $\left[\mathrm{Ca}^{2+}\right]$ by coupling $\mathrm{Ca}^{2+}$ release with the activity of $\mathrm{Ca}^{2+}-$ dependent $\mathrm{K}^{+}$channel in the granules. Finally, InsP $\mathrm{P}_{3} \mathrm{R}$ have been also localized in the secretory granules of insulin-secreting $\beta$-cells and somatostatin-secreting cells [58-60], and also in dense-core vesicles of astrocytes [61].

However, there is also a large body of evidence against the presence of InsP $\mathrm{P}_{3} \mathrm{R}$ in secretory granules. In chromaffin cells, Endo et al. [62] found that InsP $\mathrm{P}_{3} \mathrm{R}-2$ was present in the ER but not in the secretory granules. In rat insulinoma cells, $\mathrm{InsP}_{3}$ was found to release $\mathrm{Ca}^{2+}$ from the microsomal fraction but not from the secretory granules [63]. Ravazzola et al. [64] found that antibodies against InsP $_{3} \mathrm{R}$ cross-reacted with insulin, and that could be a source for artifacts in immunostaining (see also [65]). Measuring the extragranular $\left[\mathrm{Ca}^{2+}\right]$ with a phogrin-aequorin chimera, Pouli et al. [66] found no difference among the $\mathrm{Ca}^{2+}$ transients in the granule membrane and in the bulk cytosol after insulin-secreting MIN6 or phaeochromocytoma PC12 cells stimulation, indicating that no significant local $\mathrm{Ca}^{2+}$ release takes place in these cells. Similarly, using a targeted aequorin to monitor granule $\left[\mathrm{Ca}^{2+}\right]$, no effect of InsP $\mathrm{P}_{3}$ was observed in MIN6 cells [20]. Regarding zymogen granules, InsP $_{3} \mathrm{R}$ were not found using highly pure granule preparations [67] and the absence of zymogen granules did not modify the cytosolic $\mathrm{Ca}^{2+}$ transients in rat parotid acinar cells [68]. Finally, in platelets, InsP $\mathrm{P}_{3} \mathrm{R}$ are present in the dense tubular system (the equivalent of the ER) but not in the acidic granules [41].

There is also evidence for the presence of ryanodine receptors in secretory granules. The ryanodine receptor activator cyclic ADP ribose (cADPR) has been reported to release $\mathrm{Ca}^{2+}$ from zymogen granules $[55,69]$. Both cADPR and caffeine released also $\mathrm{Ca}^{2+}$ from the secretory granules of insulin-secreting MIN6 cells [20], and caffeine, but not cADPR, released $\mathrm{Ca}^{2+}$ from secretory granules in chromaffin cells [23]. The lack of effect of cADPR may reflect an insensitivity to this agonist of the ryanodine receptors in these cells, as CADPR was also unable to release $\mathrm{Ca}^{2+}$ from the ER in chromaffin cells [7]. The novel agonist nicotinic acid adenine dinucleotidephosphate (NAADP) was also effective to release $\mathrm{Ca}^{2+}$ from zymogen granules [69], platelet acidic stores [41], insulin-secreting MIN6 cells [70] and the acidic $\mathrm{Ca}^{2+}$ stores of PC12 cells [71]. The identity of the NAADP receptor is still unknown. It was initially associated with the ryanodine receptor, although other alternatives have recently appeared (two pore channels, TPCs or TPCNs, see [72]).

What do proteomic studies tell us on this point? None of the proteomic studies made up to date has detected the presence of InsP ${ }_{3} \mathrm{R}$ in the secretory granules of chromaffin [44], insulin [47,48], zymogen [45] or corticotrope granules [46]. Instead, the largest study [44] found in chromaffin granules the presence of ryanodine receptors together with several types of $\mathrm{Ca}^{2+}$ channels (voltagedependent and transient receptor potential). However, none of these proteins were detected in the other studies. Of course, if granular $\left[\mathrm{Ca}^{2+}\right]$ is nearly 1000 -fold higher than in the cytosol, at least some mechanism to accumulate $\mathrm{Ca}^{2+}$ in the granules must exist. This means that the sensitivity of these studies may not be still enough to detect proteins at very low concentrations, and further improvement of this technique may provide in the future more useful information.

\section{Conclusion}

In neuroendocrine cells, the secretory granules constitute one of the largest $\mathrm{Ca}^{2+}$ stores and its total calcium concentration is even higher than that in the ER. Given that $\mathrm{Ca}^{2+}$ is the key signal that triggers secretion of granule contents, the possible functional role of the calcium stored in the granules has attracted considerable attention for more than thirty years. The available evidence suggests moreover that intragranular $\mathrm{Ca}^{2+}$ is important for secretion [37,73-75]. However, in spite of the efforts of many research groups, most of the key questions related with granule $\mathrm{Ca}^{2+}$ homeostasis, e.g., the free granular $\left[\mathrm{Ca}^{2+}\right]$, the physical state of the stored $\mathrm{Ca}^{2+}$ or the mechanisms for $\mathrm{Ca}^{2+}$ accumulation and release from the granules, remain obscure. Further work will be necessary to clarify all these uncertainties. Besides the biochemical and physiological approaches, the new proteomic techniques look promising, but the data obtained up to date on proteins related to $\mathrm{Ca}^{2+}$ dynamics is still scarce and too variable among secretory granules of different cell types.

\section{Acknowledgments}

This work was supported by grants from Ministerio de Educación y Ciencia (BFU2008-01871) and from Junta de Castilla y León (GR105).

\section{References}

[1] M.J. Berridge, P. Lipp, M.D. Bootman, The versatility and universality of calcium signalling, Nat. Rev. 1 (2000) 11-21

[2] T. Pozzan, R. Rizzuto, P. Volpe, J. Meldolesi, Molecular and cellular physiology of intracellular calcium stores, Physiol. Rev. 74 (1994) 595-636.

[3] M. Montero, M.J. Barrero, J. Alvarez, $\left[\mathrm{Ca}^{2+}\right]$ microdomains control agonistinduced $\mathrm{Ca}^{2+}$ release in intact HeLa cells, FASEB J. 11 (1997) 881-885.

[4] R. Rizzuto, A.W. Simpson, M. Brini, T. Pozzan, Rapid changes of mitochondrial $\mathrm{Ca}^{2+}$ revealed by specifically targeted recombinant aequorin, Nature 358(1992) 325-327.

[5] M. Montero, M.T. Alonso, E. Carnicero, I. Cuchillo-Ibañez, A. Albillos, A.G. Garcia, J. Garcia-Sancho, J. Alvarez, Chromaffin-cell stimulation triggers fast millimolar mitochondrial $\mathrm{Ca}^{2+}$ transients that modulate secretion, Nat. Cell Biol. 2 (2000) 57-61.

[6] A.G. García, A.M. García de Diego, L. Gandía, R. Borges, J. García-Sancho, Calcium signaling and exocytosis in adrenal chromaffin cells, Physiol. Rev. 86 (2006) 1093-1131.

[7] M.T. Alonso, M.J. Barrero, P. Michelena, E. Carnicero, I Cuchillo, A.G. García, J. García-Sancho, M. Montero, J. Alvarez, $\mathrm{Ca}^{2+}$-induced $\mathrm{Ca}^{2+}$ release in chromaffin cells seen from inside the ER with targeted aequorin, J. Cell Biol. 144 (1999) 241-254.

[8] J.R. Haigh, R. Parris, J.H. Phillips, Free concentrations of sodium, potassium and calcium in chromaffin granules, Biochem. J. 259 (1989) 485-491.

[9] H. Winkler, E. Westhead, The molecular organization of adrenal chromaffin granules, Neuroscience 5 (1980) 1803-1823.

[10] D. Bulenda, M. Gratzl, Matrix free $\mathrm{Ca}^{2+}$ in isolated chromaffin vesicles, Biochemistry 24 (1985) 7760-7765.

[11] H. Krieger-Brauer, M. Gratzl, Influx of $\mathrm{Ca}^{2+}$ into isolated secretory vesicles from adrenal medulla. Influence of external $\mathrm{K}^{+}$and $\mathrm{Na}^{+}$, FEBS Lett. $133(1981)$ 244-246.

[12] R.G. Johnson, A. Scarpa, Ion permeability of isolated chromaffin granules, J. Gen. Physiol. 68 (1976) 601-631.

[13] R. Pezzati, M. Bossi, P. Podini, J. Meldolesi, F. Grohovaz, High-resolution calcium mapping of the endoplasmic reticulum-Golgi-exocytic membrane system. Electron energy loss imaging analysis of quick frozen-freeze dried PC12 cells, Mol. Biol. Cell 8 (1997) 1501-1512.

[14] C. Fasolato, M. Zottini, E. Clementi, D. Zacchetti, J. Meldolesi, T. Pozzan, Intracellular $\mathrm{Ca}^{2+}$ pools in PC12 cells. Three intracellular pools are distinguished by their turnover and mechanisms of $\mathrm{Ca}^{2+}$ accumulation, storage, and release, J. Biol. Chem. 266 (1991) 20159-20167. 
[15] F. Clemente, J. Meldolesi, Calcium and pancreatic secretion-dynamics of subcellular calcium pools in resting and stimulated acinar cells, Br. J. Pharmacol. 55 (1975) 369-379.

[16] J.C. Hutton, E.J. Penn, M. Peshavaria, Low-molecular-weight constituents of isolated insulin-secretory granules. Bivalent cations, adenine nucleotides and inorganic phosphate, Biochem. J. 210 (1983) 297-305.

[17] G. Nicaise, K. Maggio, S. Thirion, M. Horoyan, E. Keicher, The calcium loading of secretory granules. A possible key event in stimulus-secretion coupling, Biol. Cell 75 (1992) 89-99.

[18] J. Meldolesi, T. Pozzan, The endoplasmic reticulum $\mathrm{Ca}^{2+}$ store: a view from the lumen, Trends Biochem. Sci. 23 (1998) 10-14.

[19] I. Quesada, W.C. Chin, J. Steed, P. Campos-Bedolla, P. Verdugo, Mouse mast cell secretory granules can function as intracellular ionic oscillators, Biophys. J. 80 (2001) 2133-2139.

[20] K.J. Mitchell, P. Pinton, A. Varadi, C. Tacchetti, E.K. Ainscow, T. Pozzan, R. Rizzuto G.A. Rutter, Dense core secretory vesicles revealed as a dynamic $\mathrm{Ca}^{2+}$ store in neuroendocrine cells with a vesicle-associated membrane protein aequorin chimaera, J. Cell Biol. 155 (2001) 41-51.

[21] N.R. Mahapatra, M. Mahata, P.P. Hazra, P.M. McDonough, D.T. O'Connor, S.K. Mahata, A dynamic pool of calcium in catecholamine storage vesicles: exploration in living cells by a novel vesicle-targeted chromogranin A/aequorin chimeric photoprotein, J. Biol. Chem. 279 (2004) 51107-51121.

[22] M. Montero, J. Alvarez, W.J. Scheenen, R. Rizzuto, J. Meldolesi, T. Pozzan, $\mathrm{Ca}^{2+}$ homeostasis in the endoplasmic reticulum: coexistence of high and low $\left[\mathrm{Ca}^{2+}\right.$ subcompartments in intact HeLa cells, J. Cell Biol. 139 (1997) 601-611.

[23] J. SantoDomingo, L. Vay, M. Camacho, E. Hernández-SanMiguel, R.I. Fonteriz C.D. Lobatón, M. Montero, A. Moreno, J. Alvarez, Calciumdynamics in bovine adrenal medulla chromaffin cellsecretory granules, Eur. J. Neurosci. 28 (2008) 1265-1274.

[24] J. SantoDomingo, R.I. Fonteriz, C.D. Lobatón, M. Montero, A. Moreno, J. Alvarez, $\mathrm{Ca}^{2+}$ dynamics in the secretory vesicles of neurosecretory PC12 and INS1 cells, Cell. Mol. Neurobiol. 30 (2010) 1267-1274.

[25] J. Alvarez, M. Montero, Measuring $\left[\mathrm{Ca}^{2+}\right]$ in the endoplasmic reticulum with aequorin, Cell Calcium 32 (2002) 251-260.

[26] S.H. Yoo, Secretory granules in inositol 1,4,5-trisphosphate-dependen $\mathrm{Ca}^{2+}$ signalingin the cytoplasm of neuroendocrine cells, FASEB J. 24 (2010) 653-664.

[27] F.U. Reiffen, M. Gratzl, $\mathrm{Ca}^{2+}$ binding to chromaffin vesicle matrix proteins: effect of $\mathrm{pH}, \mathrm{Mg}^{2+}$, and ionic strength, Biochemistry 25 (1986) 4402-4406.

[28] J.S. Videen, M.S. Mezger, Y.M. Chang, D.T. O'Connor, Calcium and catecholamine interactions with adrenal chromogranins. Comparison of driving forces in binding and aggregation, J. Biol. Chem. 267 (1992) 3066-3073.

[29] W.N. Kopell, E.W. Westhead, Osmotic pressures of solutions of ATP and catecholamines relating to storage in chromaffin granules, J. Biol. Chem. 267 (1982) 5707-5710.

[30] S.H. Yoo, M.S. Lewis, Effects of $\mathrm{pH}$ and $\mathrm{Ca}^{2+}$ on monomer-dimer and monomer-tetramer equilibria of chromogranin A, J. Biol. Chem. 267 (1992) 11236-11241.

[31] S.H. Yoo, M.S. Lewis, Effects of $\mathrm{pH}$ and $\mathrm{Ca}^{2+}$ on heterodimer and heterotetramer formation by chromogranin A and chromogranin B, J. Biol. Chem. 271 (1996) 17041-17046.

[32] H. Krieger-Brauer, M. Gratzl, Uptake of $\mathrm{Ca}^{2+}$ by isolated secretory vesicles from adrenal medulla, Biochim. Biophys. Acta 691 (1982) 61-70.

[33] H. Krieger-Brauer, M. Gratzl, Effects of monovalent and divalent cations on $\mathrm{Ca}^{2+}$ fluxes across chromaffin secretory membrane vesicles, J. Neurochem. 41 (1983) 1269-1276.

[34] J.R. Haigh, J.H. Phillips, Indirect coupling of calcium transport in chromaffin granule ghosts to the proton pump, Neuroreport 4 (1993) 571-574.

[35] S. Thirion, J.D. Troadec, N.B. Pivovarova, S. Pagnotta, S.B. Andrews, R.D. Leapman, G. Nicaise, Stimulus-secretion coupling in neurohypophysial nerve endings: a role for intravesicular sodium? Proc. Natl. Acad. Sci. U.S.A. 96 (1999) 3206-3210.

[36] P.P. Goncalves, S.M. Meireles, P. Neves, M.G. Vale, Distinction between $\mathrm{Ca}^{2+}$ pump and $\mathrm{Ca}^{2+} / \mathrm{H}^{+}$antiport activities in synaptic vesicles of sheep brain cortex Neurochem. Int. 37 (2000) 387-396.

[37] C.L. Haynes, L.A. Buhler, R.M. Wightman, Vesicular $\mathrm{Ca}^{2+}$-induced secretion promoted by intracellular pH-gradient disruption, Biophys. Chem. 123 (2006) 20-24.

[38] M. Camacho, J.D. Machado, J. Alvarez, R. Borges, Intravesicular calcium release mediates the motion and exocytosis of secretory organelles, J. Biol. Chem. 283 (2008) 22383-22389.

[39] P. Fossier, M.F. Diebler, J.P. Mothet, M. Israel, L. Tauc, G. Baux, Control of the calcium concentration involved in acetylcholine release and its facilitation: an additional role for synaptic vesicles? Neuroscience 85 (1998) 85-91.

[40] J.J. López, C. Camello-Almaraz, J.A. Pariente, G. Salido, J.A. Rosado, $\mathrm{Ca}^{2+}$ accumulation into acidic organelles mediated by $\mathrm{Ca}^{2+}$ - and vacuolar $\mathrm{H}^{+}$-ATPases in human platelets, Biochem. J. 390 (2005) 243-252.

[41] J.A. Rosado, Acidic Ca ${ }^{2+}$ stores in platelets, Cell Calcium 50 (2011) 168-174.

[42] J.G. Duman, L. Chen, A.E. Palmer, B. Hille, Contributions of intracellular compartments to calcium dynamics: implicating an acidic store, Traffic 7 (2006) 859-872.

[43] P. Pinton, T. Pozzan, R. Rizzuto, The Golgi apparatus is an inositol 1,4,5trisphosphate-sensitive $\mathrm{Ca}^{2+}$ store, with functional properties distinct from those of the endoplasmic reticulum, EMBO J. 17 (1998) 5298-5308.

[44] J.L. Wegrzyn, S.J. Bark, L. Funkelstein, C. Mosier, A. Yap, P. Kazemi-Esfarjani, A.R. La Spada, C. Sigurdson, D.T. O'Connor, V. Hook, Proteomics of dense core secretory vesicles reveal distinct protein categories for secretion of neuroeffectors for cell-cell communication, J. Proteome Res. 9 (2010) 50025024.

45] M.J. Rindler, C.F. Xu, I. Gumper, N.N. Smith, T.A. Neubert, Proteomic analysis of pancreatic zymogen granules: identification of new granule proteins, J. Proteome Res. 6 (2007) 2978-2992.

[46] D.J. Gauthier, J.A. Sobota, F. Ferraro, R.E. Mains, C. Lazure, Flow cytometryassisted purification and proteomic analysis of the corticotropes dense-core secretory granules, Proteomics 8 (2008) 3848-3861.

[47] H.S. Lee, J. Jeong, K.-J. Lee, Characterization of vesicles secreted from insulinoma NIT-1 cells, J. Proteome Res. 8 (2009) 2851-2862.

[48] Y. Brunner, Y. Coute, M. Iezzi, M. Foti, M. Fukuda, D.F. Hochstrasser, C.B. Wollheim, J.-C. Sanchez, Proteomics analysis of insulin secretory granules, Mol. Cell. Proteomics 6 (2007) 1007-1017.

[49] S.H. Yoo, J.P. Albanesi, Inositol 1,4,5-trisphosphate-triggered $\mathrm{Ca}^{2+}$ release from bovine adrenal medullary secretory vesicles, J. Biol. Chem. 265 (1990) 13446-13448.

[50] Y.H. Huh, J.A. Yoo, S.J. Bahk, S.H. Yoo, Distribution profile of inositol 1,4,5trisphosphate receptor isoforms in adrenal chromaffin cells, FEBS Lett. 579 (2005) 2597-2603.

[51] S.H. Yoo, Y.S. Oh, M.K. Kang, Y.H. Huh, S.H. So, H.S. Park, H.Y. Park, Localization of Three types of the inositol 1,4,5-trisphosphate receptor $/ \mathrm{Ca}^{2+}$ channel in the secretory granules and coupling with the $\mathrm{Ca}^{2+}$ storage proteins chromogranins A and B, J. Biol. Chem. 276 (2001) 45806-45812.

[52] E.C. Thrower, H.Y. Park, S.H. So, S.H. Yoo, B.E. Ehrlich, Activation of the inositol 1,4,5-trisphosphate receptor by the calcium storage protein chromogranin A J. Biol. Chem. 277 (2002) 15801-15806.

[53] S.H. Yoo, Coupling of the $\mathrm{IP}_{3}$ receptor $/ \mathrm{Ca}^{2+}$ channel with $\mathrm{Ca}^{2+}$ storage proteins chromogranins A and B in secretory granules, Trends Neurosci. 23 (2000) 424-428.

[54] S.H. Yoo, Y.H. Huh, Y.S. Hur, Inositol 1,4,5-trisphosphate receptor in chromaffin secretory granules and its relation to chromogranins, Cell. Mol. Neurobiol. 30 (2010) 1155-1161.

[55] O.V. Gerasimenko, J.V. Gerasimenko, P.V. Belan, O.H. Petersen, Inositol trisphosphate and cyclic ADP-ribose-mediated release of $\mathrm{Ca}^{2+}$ from single isolated pancreatic zymogen granules, Cell 84 (1996) 473-480.

[56] O.V. Gerasimenko, J.V. Gerasimenko, R. Rizzuto, M. Treiman, A.V. Tepikin, O.H Petersen, The distribution of the endoplasmic reticulum in living pancreatic acinar cells, Cell Calcium 32 (2002) 261-268.

[57] T. Nguyen, W.C. Chin, P. Verdugo, Role of $\mathrm{Ca}^{2+} / \mathrm{K}^{+}$ion exchange in intracellula storage and release of $\mathrm{Ca}^{2+}$, Nature 395 (1998) 908-912.

[58] O. Blondel, M.M. Moody, A.M. Depaoli, A.H. Sharp, C.A. Ross, H. Swift, G.I. Bell, Localization of inositol trisphosphate receptor subtype 3 to insulin and somatostatinsecretory granules and regulation of expression in islets and insulinoma cells, Proc. Natl. Acad. Sci. U.S.A. 91 (1994) 7777-7781.

[59] O. Blondel, G.I. Bell, S. Seino, Inositol 1,4,5-trisphosphate receptors, secretory granules and secretion in endocrine and neuroendocrine cells, Trends Neurosci. 18 (1995) 157-161.

[60] L. Xie, M. Zhang, W. Zhou, Z. Wu, J. Ding, L. Chen, T. Xu, Extracellular ATP stimulates exocytosis via localized $\mathrm{Ca}^{2+}$ release from acidic stores in rat pancreatic $\beta$-cells, Traffic 7 (2006) 429-439.

[61] Y.S. Hur, K.D. Kim, S.H. Paek, S.H. Yoo, Evidence for the existence of secretory granule (dense-core vesicle)-based inositol 1,4,5-trisphosphate-dependent $\mathrm{Ca}^{2+}$ signaling system in astrocytes, PLoS ONE 5 (2010) 1-13.

[62] Y. Endo, K. Harada, N. Fujishiro, H. Funahashi, S. Shioda, G.D. Prestwich, K. Mikoshiba, M. Inoue, Organelles containing inositol trisphosphate receptor type 2 in adrenal medullary cells, J. Physiol. Sci. 56 (2006) 415-423.

[63] M. Prentki, T.J. Biden, D. Janjic, R.F. Irvine, M.J. Berridge, C.B. Wollheim, Rapid mobilization of $\mathrm{Ca}^{2+}$ from rat insulinoma microsomes by inositol-1,4,5trisphosphate, Nature 309 (1984) 562-564.

[64] M. Ravazzola, P.A. Halban, L. Orci, Inositol 1,4,5-trisphosphate receptor subtype 3 in pancreatic islet cell secretory granules revisited, Proc. Natl. Acad. Sci. U.S.A. 93 (1996) 2745-2748.

[65] J. Meldolesi, T. Pozzan, $\mathrm{IP}_{3}$ receptors and secretory granules, Trends Neurosci. 18 (1995) 340-341.

[66] A.E. Pouli, N. Karagenc, C. Wasmeier, J.C. Hutton, N. Bright, S. Arden, J.C. Schofield, G.A. Rutter, A phogrin-aequorin chimaera to image free $\mathrm{Ca}^{2+}$ in the vicinity ofsecretory granules, Biochem. J. 330 (1998) 1399-1404.

[67] D.I. Yule, S.A. Ernst, H. Ohnishi, R.J.H. Wojcikiewicz, Evidence that zymogen granules are not a physiologically relevant calcium pool. Defining the distribution of inositol 1,4,5-trisphosphate receptors in pancreatic acinar cells, J. Biol. Chem. 272 (1997) 9093-9098

[68] A. Nezu, A. Tanimura, T. Morita, K. Irie, T. Yajima, Y. Tojyo, Evidence that zymogen granules do not function as an intracellular $\mathrm{Ca}^{2+}$ store for the generation of the $\mathrm{Ca}^{2+}$ signal in rat parotid acinar cells, Biochem. J. 363 (2002) 59-66.

[69] J.V. Gerasimenko, M. Sherwood, A.V. Tepikin, O.H. Petersen, O.V. Gerasimenko, NAADP, cADPR and $\mathrm{IP}_{3}$ all release $\mathrm{Ca}^{2+}$ fromtheendoplasmicreticulumandanacidicstore in the secretory granule area, J. Cell Sci. 119 (2006) 226-238.

[70] K.J. Mitchell, F.A. Lai, G.A. Rutter, Ryanodine receptor type I and nicotinic acid adenine dinucleotide phosphate receptors mediate $\mathrm{Ca}^{2+}$ release from insulincontaining vesicles in living pancreatic beta-cells (MIN6), J. Biol. Chem. 278 (2003) 11057-11064.

[71] E. Brailoiu, D. Churamani, V. Pandey, G.C. Brailoiu, F. Tuluc, S. Patel, N.J. Dun, Messenger-specific role for nicotinic acid adenine dinucleotide phosphate in neuronal differentiation, J. Biol. Chem. 281 (2006) 15923-15928. 
[72] P. Calcraft, M. Ruas, Z Pan, X. Cheng, A. Arredouani, X. Hao, J. Tang, K. Rietdorf, L. Teboul, K.T. Chuang, P. Lin, R. Xiao, C. Wang, Y. Zhu, Y. Lin, C.N. Wyatt, J. Parrington, J. Ma, A.M. Evans, A. Galione, M.X. Zhu, NAADP mobilizes calciumfrom acidic organelles through two-pore channels, Nature 459 (2009) 596-600.

[73] W.J. Scheenen, C.B. Wollheim, T. Pozzan, C. Fasolato, $\mathrm{Ca}^{2+}$ depletion from granules inhibits exocytosis. A study with insulin-secreting cells, J. Biol. Chem. 273 (1998) 19002-19008.
[74] M.L. Mundorf, K.P. Troyer, S.E. Hochstetler, JA. Near, R.M. Wightman, Vesicular $\mathrm{Ca}^{2+}$ participates in the catalysis of exocytosis, J. Biol. Chem. 275 (2000) 9136-9142.

[75] J.D. Machado, M. Camacho, J. Alvarez, R. Borges, On the role of intravesicular calcium in the motion and exocytosis of secretory organelles, Communicative Integrative Biol. 2 (2009) 1-3. 